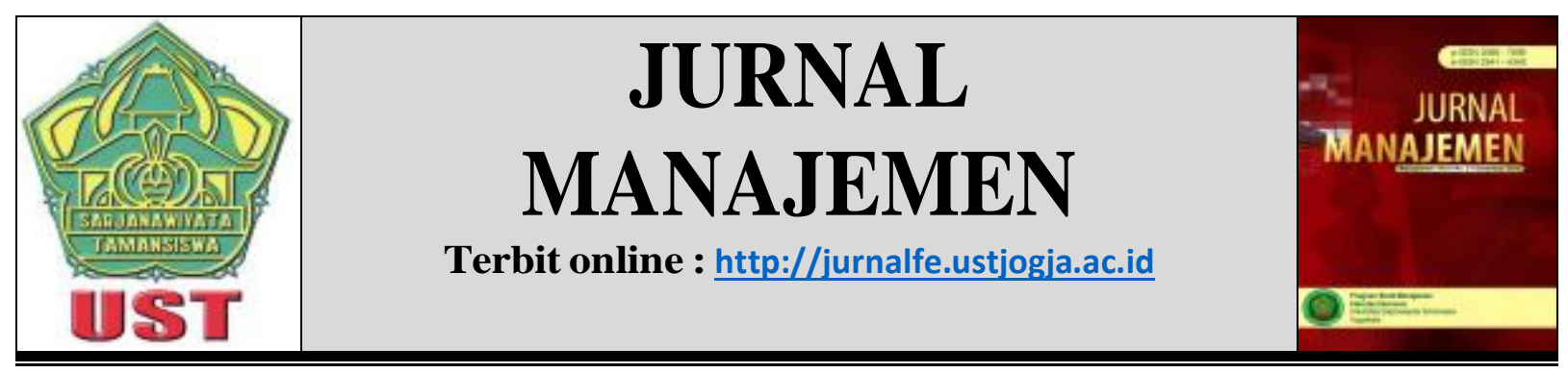

\title{
PENILAIAN KINERJA KEUANGAN PERUSAHAAN DENGAN MENGGUNAKAN METODE ECONOMIC VALUE ADDED (STUDI KASUS PADA PERUSAHAAN PROPERTI DAN REAL ESTATE YANG TERCATAT DI BURSA EFEK INDONESIA)
}

\author{
Wijayanti ${ }^{1}$ \\ Mujino $^{2}$ \\ 1)Alumni Jurusan Manajemen Fakultas Ekonomi Universitas Sarjanawiyata \\ Tamansiswa Yogyakarta \\ 2)Dosen Jurusan Manajemen Fakultas Ekonomi Universitas Universitas \\ Sarjanawiyata Tamansiswa Yogyakarta \\ Korespondensi:mujinoust@gmail.com
}

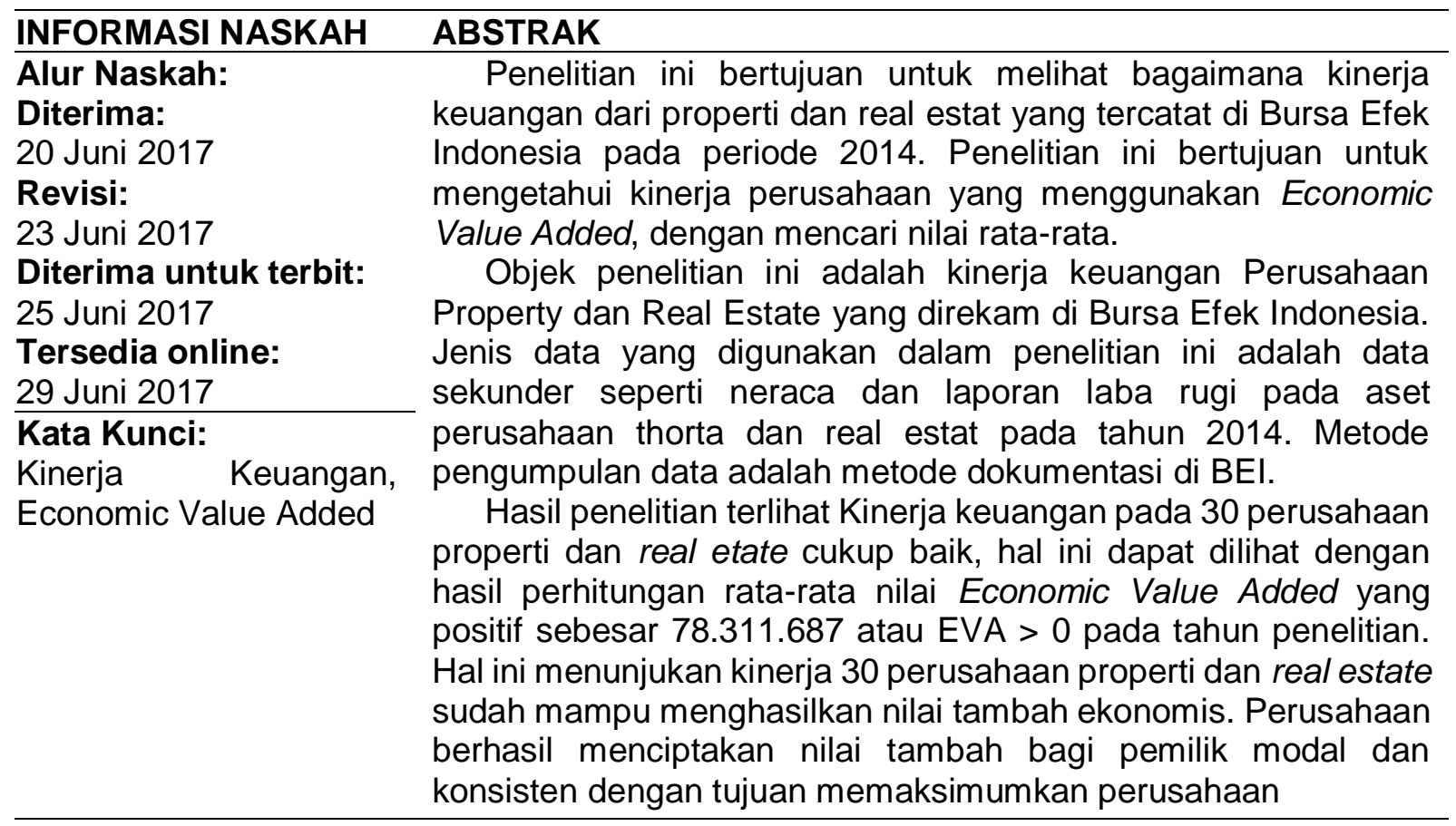




\section{PENDAHULUAN}

Sesuai perkembangan jaman dimulai dengan perkembangan ilmu pengetahuan dan teknologi yang semakin hari semakin pesat diikuti oleh peningkatan pembangunanpembangunan negara berkembang di wilayah asia tenggara yang semakin maju. Hal ini negara Indonesia dituntut untuk mampu mengimbangi agar tidak tertinggal dengan negara-negara lainnya khususnya pembangunan infrastruktur, Dengan pembangunan akan banyak memicu kemajuan pada sektor perekonomian. Dalam proses peningkatan pembangunan negara Indonesia akan menimbulkan banyaknya perusahaan dibidang properti dan real estate, sehingga akan mencul pengusaha-pengusaha baru dibidang jasa tersebut, tentu juga akan meningkatkan jumlah investor yang akan menanamkan modalnya diperusahaan tersebut. Sesuai penjelasan diatas tentu perusahaan dibidang properti dan real estate sangatlah menjanjikan baik untuk perusahaan itu sendiri, pemerintah dan pemegang saham. Disamping dengan keuntungan yang tinggi diikuti pajaknya yang tinggi dan tentu memberikan prospek bagi pemegang saham, investor dan manajemen. Perusahaan perlu mencari alat ukur kinerja terbaik yang dapat diandalkan sebagai dasar pengambilan keputusan investasinya jangka panjang. Oleh karena itu penulis disini akan melakukan penelitian dengan judul "Penilaian Kinerja Keuangan Perusahaan Dengan Metode Economic Vallue Added (studi kasus pada perusahaan properti dan real estate yang tercatat pada Bursa Efek Indonesia)"

\section{KAJIAN PUSTAKA DAN HIPOTESIS Definisi Kinerja Keuangan}

Menurut Irhan Fahmi (2011) kinerja keungan adalah suatu analisis yang dilakukan untuk melihat sejauh mana suatu perusahaan telah melaksanakan dengan menggunakan aturan-aturan pelaksanaan keuangan secara baik dan benar.

\section{Pengertian Laporan Keuangan}

Menurut Sofyan Syafri Harahap, (2002) : Laporan keuangan merupakan media yang paling penting untuk menilai prestasi dan kondisi ekonomis perusahaan. Laporan keuangan menggambarkan kondisi keuangan dan hasil usaha suatu perusahaan pada waktu tertentu atau jangka waktu tertentu.

\section{Economic Value Added (EVA)}

Menurut Amin Widjaja Tunggal (2001), Economic Value Added adalah suatu system manajemen keuangan untuk mengukur laba ekonomi dalam suatu perusahaan, yang menyatakan bahwa kesejahteraaan hanya dapat tercipta jika perusahaan mampu memenuhi semua biaya operasi (operating cost) dan biaya modal (cost of capital)

\section{Perhitungan Economic Value Added (EVA)}

Menurut Young \& O’Byme (2001;39), definisi Economic Value Added adalah : EVA sama dengan selisih antara laba operasi perusahaan setelah pajak (NOPAT) dengan biaya modal. Biaya modal sama dengan modal yang diinvestasikan perusahaan dikalikan dengan biaya modal rata-rata tertimbang. Secara matematis dirumuskan sebagai berikut:

Berikut langkah-langkah perhitungan Economic Value Added menurut Young \& O’Byme:

$$
E V A=N O P A T-(\text { WACC } \mathrm{x} \text { Modal yang diinvestasikan })
$$




\begin{tabular}{ll}
\hline Komponen EVA & $\begin{array}{c}\text { Rumus perhitungan masing masing } \\
\text { komponen }\end{array}$ \\
\hline WACC & $\left(\mathrm{k}_{\mathrm{e}} \times \mathrm{We}\right)+([\mathrm{kd}(1-\mathrm{t})] \mathrm{Wd}$ \\
NOPAT & EBIT (1-tarif pajak) \\
Modal yang & Kewajiban jangka panjang + Ekuitas \\
diinvestasikan & $\begin{array}{l}\text { pemegang saham } \\
\text { EVA }\end{array}$ \\
& $\begin{array}{l}\text { NOPAT - (WACC } \times \text { Modal yang } \\
\text { diinvestasikan })\end{array}$ \\
\hline
\end{tabular}

Menurut Tunggal (2001), Net Operating After Tax adalah laba yang didapatkan dari operasi-operasi perubahan setelah pajak tetapi sebelum membiayai biaya-biaya dan noncash bookkeeping seperti biaya penyusutan. Dengan demikian NOPAT dapat juga diartikan sebagai jumlah laba yang tersedia untuk memberikan pengembalian (return) tunai kepada penyedia dana untuk modal persediaan.

Menurut Young (2001), NOPAT merupakan laba yang diperoleh dari hasil operasi perusahaan setelah dikurangi pajak. Dimana rumus perhitungannya adalah

$N O P A T=E B I T D A-$ Penyusutan dan amortisasi - pajak

Atau dengan rumus : NOPAT $=E B I T-(1-\mathrm{t})$

\section{Weighted Average Cost of Capital (WACC)/ Biaya Modal Rata-rata Tertimbang}

Menurut Rudianto (2006) definisi biaya modal rata-rata tertimbang adalah sebagai berikut: biaya modal rata-rata tertimbang adalah rata-rata tertimbang dari berbagai biaya modal khusus pasa saat tertentu. Biaya modal rata-rata tertimbang dihitung dengan cara menjumlahkan biaya modal proporsional dari setiap jenis modal yang digunakan perusahaan untuk berinvestasi.

Menurut Young \& O'Byrne (2001) Biaya modal rata-rata tertimbang (WACC) dapat dihitung sebagai berikut:

WACC $=$ Utang/pembiayaan total (biaya utang) $(1-\mathrm{T})+$ ekuitas : pembiayaan total

Invested Capital (Modal yang diinvestasikan) (biaya ekuitas)

Menurut Young (2001) modal yang diinvestasikan adalah jumlah seluruh keuangan, terlepas dari kewajiban jangka pendek, passiva yang tidak mengandung bunga (non interestbearing liabilities), seperti utang, upah yang akan jatuh tempo (accrued wages) dan pajak yang akan jatuh tempo (accrued taxes). Modal yang diinvestasikan sama dengan jumlah ekuitas pemegang saham, seluruh utang jangka pendek dan jamgka panjang yang menanggung bunga, utang dan kewajiban jangka panjang lainnya.

Rumus perhitungan invested capital sebagai berikut:

Modal yang diinvestasikan = Kewajiban jangka panjang + Ekuitas pemegang saham

\section{Kategori Penilaian Kinerja dengan Metode EVA}

Menurut (Rudianto, 2006) Hasil penilaian kinerja suatu perusahaan dengan menggunakan ukuran Economic Value Added dapat dikelompokan ke dalam 3 kategori yang berbeda, yaitu sebagai berikut.

1. Nilai EVA $>0$ atau EVA bernilai positif 
Pada posisi ini berarti manajemen perusahaan telah berhasil menciptakan nilai tambah ekonomis bagi perusahaan.

2. Nilai $\mathrm{EVA}=0$

Pada posisi ini berarti manajemen perusahaan berada dalam titik impas. Perusahaan tidak mengalami kemunduran tetapi sekaligus tidak mengalami kemajuan secara ekonomis.

3. Nilai EVA $<0$ atau Eva bernilai negatif

Pada posisi ini berarti tidak terjadi proses pertambahan nilai nilai ekonomis bagi perusahaan, dalam arti laba yang dihasilkan tidak dapat memenuhi harapan para kreditur dan pemegang saham perusahaan (investor)

\section{METODE PENELITIAN}

\section{Sifat Penelitan}

Sifat penelitian ini berupa diskriptif kuantitatif dimana penulis disini mendiskripsikan data berupa hasil yang telah dianalisis berupa data kuantitatif atau berupa angka.

\section{Sumber dan Metode Pengumpulan Data}

Sumber pengumpulan data pada penelitian ini adalah data sekunder yang berupa neraca dan laporan laba rugi 2014 pada perusahaan yang terdaftar di Bursa Efek Indonesia.

\section{Metode Pengumpulan Data}

Metode dalam pengumpulan data pada penelitian ini dengan metode dokumentasi. Dimana dokumentasi tersebut diambil dari laporan keuangan pada tahun 2014 yang telah dipublikasikan di Bursa Efek Indonesia.

\section{HASIL DAN PEMBAHASAN}

Untuk mengetahui kinerja keuangan pada 30 perusahaan properti dan real etate yang terdaftar di Bursa Efek Indonesia pada tahun 2014 dengan menggunakan metode Economic Value Added, disini penulis menggunakan rumus:

$$
E V A=N O P A T-(W A C C \times \text { Modal yang diinvestasikan })
$$

Dimana dalam perhitungan menggunakan metode ini perlu mengetahui komponenkomponenya antara lain:

Perhitungan Net Operating Profit After Taxes (NOPAT)

$$
\begin{aligned}
\text { Rata }- \text { rata NOPAT }= & \frac{R p .12 .141 .121 .550 .989}{30 \text { perusahaan }} \\
& =R p .404 .704 .051 .700
\end{aligned}
$$

Dapat diketahui hasil nilai rata-rata NOPAT pada 30 perusahaan sebesar Rp.404.704.051.700. Dari 30 perusahaan properti dan real estate rata-rata nilai NOPAT Positif dalam tahun penelitian, hal ini menunjukan bahwa laba usaha sebelum bunga dan pajak penghasilan sudah mampu menutup beban pajak. Nilai NOPAT tertinggi yang dihasilkan adalah PT Lippo Cikarang Karawaci Tbk (LPKR) sebesar Rp.2.742.328.883 pada tahun penelitian, hal ini berati dari 30 perusahaan properti dan real estate perusahaan tersebut paling baik kinerjanya dapat dibuktikan dari laba operasi setelah pajaknya yang tinggi. PT Lami Citra Nusantara tbk (LAMI) memiliki hasil NOPAT terendah sebesar Rp.60.858.849 hal ini disebabkan kinerja dalam memperoleh laba operasi juga paling buruk diantara lainnya. 


\section{Menghitung Modal yang Diinvestasikan (Invested Capital)}

$$
\begin{aligned}
\text { Rata }- \text { rata Modal yang diinvestasikan }= & \frac{R p .145 .873 .357 .047 .021}{30 \text { perusahaan }} \\
& =R p .4 .862 .445 .234 .901
\end{aligned}
$$

Dapat dilihat hasil total rata-rata modal yang diinvestasikan pada 30 perusahaan properti dan real estate mencapai Rp.4.862.445.234.901 dalam tahun penelitian. Dengan nilai rata-rata modal yang diinvestasikan pada 30 perusahaan properti dan real estate yang relatif tinggi hal ini disebabkan karena dalam sektor properti dan real estate ini banyak diminati para investor untuk menanamkan sahamnya keperusahaan-perusahaan tersebut.

Rata- rata modal yang diinvestasikan sebesar Rp. 4.862.445.234.901 dalam tahun penelitian cukup besar hal ini juga karena perusahaan-perusahaan pada sektor ini cukup aktif dalam menghimpun dana dari para investor.

\section{Biaya Modal Rata-rata Tertimbang/ Weight Average Cost of Capital(WACC)}

Rumus:

$$
\text { WACC }=\text { Utang/Pembiayaan total (biaya utang) }(1-\mathrm{T})+
$$

Ekuitas/Pembiayaan Total (biaya ekuitas)

Dari rumus tersebut, maka perlu dihitung nilai biaya utang, biaya Ekuitas dan Tingkat Pajak (T) dan sebagai berikut:

a. Perhitungan Biaya Utang

$$
\begin{aligned}
\text { Rata }- \text { rata Biaya Hutang }= & \frac{45,09347 \%}{30 \text { perusahaan }} \\
& =1,503116 \%
\end{aligned}
$$

Dapat dilihat bahwa rata-rata biaya hutang dari 30 perusahaan properti dan real estate mencapai $1,503116 \%$. Hal ini menunjukan beban yang ditanggung oleh 30 perusahaan properti dan real estate dalam penggunaan dan pinjaman dari debitur sebesar $1,503116 \%$ pada tahun penelitian.

b. Perhitungan Biaya Ekuitas

$$
\begin{aligned}
& \text { Rata }- \text { rata biaya ekuitas }=\frac{330 \%}{30 \text { perusahaan }} \\
& =11 \%
\end{aligned}
$$

Dapat dilihat bahwa nilai rata-rata biaya ekuitas pada tahun penelitian sebesar $11 \%$, hal ini berarti total tingkat rata-rata pengembalian hasil yang diharapkan dari modal yang diinvestasikan oleh para investor pada perusahan poperti dan real estate sebesar $11 \%$ pada tahun penelitian.

c. Perhitungan Tingkat Pajak (T)

Tingkat pajak dalam penelitian ini menggunakan peraturan perundang-undangan terbaru yaitu UU PPh nomor 36 tahun 2008 yang mulai berlaku pada 1 Januari 2009 yang berisikan tarif $\mathrm{PPh}$ menganut tarif proporsional. Mulai tahun 2010 tarif $\mathrm{PPh}$ menganut sistem tarif tunggal atau single tax yaitu $28 \%$. Jadi berapapun penghasilan kena pajaknya, tarif yang dikenakan adalah satu $28 \%$.

Setelah mengetahui nilai komponen-komponen perhitungan WACC: 


$$
\begin{aligned}
\text { Rata }- \text { rata } W A C C= & \frac{193,7263 \%}{30 \text { perusahaan }} \\
& =6,457542 \%
\end{aligned}
$$

dapat dilihat bahwa nilai rata-rata WACC pada 30 perusahaan properti dan real estate sebesar $6,45 \%$, hal ini menunjukan tingkat biaya penggunaan modal perusahaan secara keseluruhan mencapai $6,45 \%$. PT Lippo Cikarang Karawaci Tbk (LPCK) memiliki nilai WACC yang paling tinggi yaitu sebesar 19,6\%, hal ini karena pada perusahaan tersebut paling aktif dalam menghimpun dana pada tahun penelitan.

\section{Economic Value Added}

Perhitungan kinerja keuangan dengan menggunakan metode Economic Value Added pada penelitian ini menggunakan rumus:

$$
\begin{aligned}
\text { Rata }- \text { rata Economic Value Added }= & \frac{R p \cdot 2.349 .350 .617}{30 \text { perusahaan }} \\
& =R p .78 .311 .687
\end{aligned}
$$

yang sudah terlampir dapat diliat nilai economic value added pada perusahaan properti dan real estate dengan nilai rata-rata Economic Value Added mencapai Rp. 78.311.687, dengan nilai EVA tertinggi diperoleh pada PT. Kawasan Industri Jababeka Tbk (KIJA) sebesar Rp. 526.458.073.191 dan nilai terendah EVA diperoleh pada PT Bumi Serpong Damai Tbk (BSDE) sebesar-Rp.1.567.460.140.514.

Dengan rata-rata nilai EVA pada perusahaan properti dan real estate sebesar Rp.78.311.687 hal ini menunjukan rata-rata kinerja perusahaan properti dan real estate dalam menciptakan nila tambah ekonomi cukup baik. Nilai rata-rata $E V A$ positif atau $E V A>0$ hal ini menunjukan bahwa perusahaan berhasil menciptakan nilai tambah bagi pemilik modal dan konsisten dengan tujuan memaksimumkan perusahaan.

Dengan nilai rata-rata EVA positif hal ini dkarenakan nilai Net Operating After Tax atau Laba Operasi setelah pajak yang dihasilkan perusahaan tersebut cukup tinggi, sehingga dengan tingkat pengembalian yang dihasilkan melebihi tingkat biaya modal atau tingkat pengembalian sesuai dengan yang diharapkan oleh investor. Dengan kondisi ini untuk menanamkan sahamnya disektor ini juga menjanjikan, didukung dengan kondisi negara Indonesia negara berkembang dengan ekspansi perekonomian Indonesia yang subur, populasi penduduk yang tinggi dan pola hidup masyarakat yang konsumtif dan daya beli masyarakat yang menguat akan membuat tingkat permintaan pada sektor ini terus meningkat.

\section{PENUTUP}

Dari hasil analisis dan pembahasan dari bab sebelumnya oleh peneliti, maka dapat diambil kesimpulannya sebagai berikut, Kinerja keuangan pada 30 perusahaan properti dan real etate cukup baik, hal ini dapat dilihat dengan hasil perhitungan rata-rata nilai Economic Value Added yang positif sebesar 78.311.687 atau EVA $>0$ pada tahun penelitian. Hal ini menunjukan kinerja 30 perusahaan properti dan real estate sudah mampu menghasilkan nilai tambah ekonomis. Perusahaan berhasil menciptakan nilai tambah bagi pemilik modal dan konsisten dengan tujuan memaksimumkan perusahaan 


\section{DAFTAR PUSTAKA}

Gunawan, Budi. 2014. Analisis Return On Asset (ROA), Economic Value Added (EVA) dan Market Value Added (MVA) Terhadap Kinerja Keuangan Perusahaan PT. Perkebunan Nusantara III (Persero). Yogyakarta: Skripsi Fakultas Ekonomi Universitas Sarjanawiyata Tamansiswa

Harahap, Sofyan Syafri. 2002. Analisis Kritis atas Laporan Keuangan. Jakarta: Rajawali Pers Hidayah, Vifin Sholfiatin Nur. 2008. Analisis Economic Value Added untuk Mengukur Kinerja Keuangan Pada PT. HM. Sampoerna Tbk. (Sebelum dan sesudah Akuisisi Periode Tahun 2003-2007). Malang: Skripsi Fakultass Ekonomi Universitas Negeri Malang. Diunduh pada jurnal pukul 20.50 WIB

Mulyadi. 2003. "Akuntansi Manajemen". Jakarta Selatan. Salemba

Munawir. 2000. Analisis Laporan Keuangan, cetakan keempat. Yogyakarta: PT Liberty

O’Byrne, Stephen dan Young., S David.2001. EVA dan Managemen Berdasarkan Nilai. BPFE Prihadi, Toto.2013. Analisis Laporan Keuangan Lanjutan.Jakarta Pusat: PPM

Ristasari, Vevri Pryutias.2015. Penilaian Kinerja Keuangan Pada PT Indosat Tbk dan PT XL Axiata Tbk.Yogyakarta: Skripsi Fakultas Ekonomi Universitas Sarjanawiyata Tamansiswa

Rudianto. 2006. Akuntansi Manajemen Informasi Untuk Pengambilan Keputusan Manajemen. Jakarta: PT Grasindo

Rudianto. 2006. Dasar-dasar Akuntansi. Jakarta: PT Grasindo

Sartono, Agus. Manajemen Keuangan Teori dan Aplikasi Edisi 4. Yogyakarta. BPFE

Sawir, Agnes. 2005. Analisis Kinerja Keuangan dan Perencanaan Keuangan Perusahaan. Jakarta: Gramedia

Sugiono, Arief. 2009. Manajemen Keuangan Untuk Praktisi Keuangan. Jakarta: Grasindo.

Tunggal, Amin Widjaja. 2001. Memahami Konsep Economic Value Added (EVA) dan Value Based Management (VBM). Jakarta: Harvarindo 